\title{
DIFFICULTIES IN THE PROVISION OF ISOLATION HOSPITALS.*
}

\author{
By R. FORSYTH, M.D., \\ Medical Officer of Health of Birstall, Birkenshaw, and Drighlington Urban \\ Districts. \\ President of the Yorkshire Branch of the Society.
}

As medical officers of health we are all interested in isolation hospitals and their erection. It is not my intention to-day to give any elaborate address on the difficulties experienced by local authorities, medical officers of health, and those interested in and wishful to promote sanitary work, more especially that part in connection with isolation hospitals, in a thorough and efficient manner, but to give you a short description of the difficulties that have kept cropping up from time to time in connection with the erection of the Oakwell Joint Hospital, which is to serve for infectious cases in the urban distriets of Birstall, Birkenshaw, Gomersal, Gildersome, and Drighlington, and to which hospital board I have the honour to be medical officer.

I wish to place before you the various steps taken, and show, firstly, the difficulty we experienced in obtaining a site, and, secondly, the delay in carrying out the erection of the buildings, owing to the short period the Local Government Board granted for the repayment of the loans necessary to carry out the work; this would of necessity have caused the districts to be rather heavily rated to meet the expenditure, and rather than consent to this the Council, seeing that the Local Government Board would not grant the terms asked for, decided to curtail the scheme and erect buildings not quite so expensive as originally intended.

The idea of the hospital provision arose from the fact that no accommodation existed in the urban districts of Birstall, Birkenshaw, and Drighlington. In the first place, we have been a long time about our work. From the year 1894 to 1896 several informal meetings were held by representatives of these districts to see if some arrangement could be arrived at for a joint hospital board, and ultimately a provisional order was obtained on May 12th, 1896, constituting the Oakwell Joint Hospital Board for the urban districts of Birstall, Birkenshaw and Drighlington. The first meeting of this Board was held on December 18th, 1896, at which meeting a resolution was passed to inquire for 'a site.

* Presidential Address. 
Here the difficulties at once began. Several sites were selected as suitable, but in one case the owner would have nothing to do with a hospital on his land; another site was thought to be too far away from some parts of the districts, another very likely one was rather inaccessible from the main roads. Latterly the present site, "the Foxhall Estate," consisting of about eight acres, was fixed upon, and the representative of the owners, six or seven in number, was quite prepared to sell, and arranged with the Board; but, unfortunately, the owners were not all of one mind, and one more especially held out for better terms and refused to sign the agreement even after the representative had closed the bargain and completed the contract. All this meant loss of valuable time and delay in carrying out the scheme.

In the meantime, however, whilst all these transactions were going on, Gomersal Council, in March, 1897, commenced negotiations to be added to the Board, and in March, 1898, a provisional order from the Local Government Board, including Gomersal, was obtained. In June of the same year Mr. J. W. Burrows, the architect selected, was instructed to prepare plans; these were submitted and approved by the Board in September.

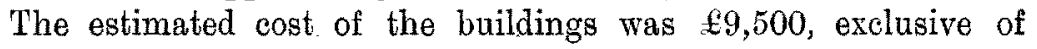
land and furnishing, the number of beds arranged for being thirty.

Application was now made to the Local Government Board for sanetion for a loan of $\$ 13,000$.

Shortly after this application was made Gildersome District Council intimated a desire to join the Board, and a provisional order including Gildersome was subsequently granted.

In November the Local Government Board gave sanetion to the Board to borrow $\$ 13,000$, repayable in twenty-seven years. This they declined, owing to the heavy rate that would be required to meet the cost in the term of years proposed, and urged for the period to be extended to forty or fifty years. The Local Government Board would not consent to this, but subsequently in June, 1900 , offered to issue three separate sanctions, one for purchase of land repayable in fifty years, one for buildings repayable in thirty years, and one for furnishing repayable in ten years. This was not accepted, and in December, 1900, the Board decided to have the plans modified, at the same time accepting the Local Government Board's sanction for borrowing to complete the purchase of the land. In April, 1901, the plans were further considered, and not till April, 1902, were they accepted and the architect instructed to advertise for tenders. 
In June the tenders for building were accepted, and a few days after this the purchase of the estate was also completed.

The tenders for building were really accepted a short time before the purchase of the ground was completed, owing to the stubbornness of one man, who held out for more money. The tenders

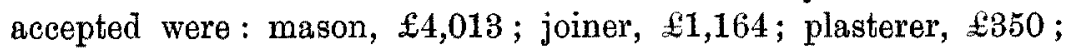
ainter, $£ 75$; plumber and glazier, $\$ 765$; slater, \&326. Total, $£ 6,698$. The number of beds, 26 .

I will now briefly describe the site and the buildings in course of erection.

The site is at a high altitude-580 feet above sea-level-and a short distance from the Great Northern Railway between Howdenclough and Drighlington, easy of access from all parts of the various districts, and is well isolated.

The buildings to be erected are: administrative block, containing on ground-floor matron's and doctors' room, dispensary, matron's storeroom, nurses' dining and sitting room, lavatory and waterclosets, kitchen, scullery, pantries, caretaker's living-room with separate entrance-porch, caretaker's bedroom; in addition to the front entrance there are separate entrances for nurses and tradesmen.

The corridors and staircases are of good width. On first-floor, in addition to the matron's bedroom, there are six bedrooms for nurses and probationers, two linen stores, bathroom, etc., and housemaids' sink-closet.

The scarlet fever, enteric and half isolation pavilions, one-storied, will each contain two wards. Accommodation will be provided in each of the scarlet-fever wards for eight beds, enteric four beds, and isolation one bed, twenty-six in all, together with the nurses' duty rooms, bathrooms and storerooms in conneetion with each department.

Laundry. - The laundry block will consist of washhouse, finishing and ironing rooms, to be fitted up with the newest apparatus and steam-power machinery, boiler-house, stable, ambulance shed, infected and disinfected van sheds, and other outbuildings.

A steam disinfector is to be placed between two rooms with a basement for a calorifier.

Mortuary.-This will contain two slabs, lavatory, sink, ete. Annexed to this will be a visitors' lobby, separated from the mortuary by an air-tight glazed screen, and entered by a separate external door.

Discharge Block.-Contains undressing room, bathroom, and dressing-room, and is placed near the main entrance gates.

The buildings are to be erected in brick. 
The floors are polished maple and the walls of the pavilions finished inside with parian cement.

The woodwork is of pitch pine.

Ventilation.-This will be done by extract ventilators placed on the roofs, and upcast inlet ventilators in the walls.

Heating.-The wards will be heated by Shoreland's hospital stoves, descending flues; the supply of water for the baths and sinks will be obtained from the calorifier in the laundry block heated by steam from a large Cornish boiler, a large cistern being placed over the boiler-house to supply the water to the calorifier sufficient for all the pavilions.

Drainage.-As there is no main sewer nearer than about a mile to the site, two systems are being provided, one for surface water, the other for sewage.

By gravitation the sewage will be conducted to two pairs of bacteria beds, which are to be used alternately; before reaching the beds the sewage will pass into a septic tank, to be delivered by Adams' or Mather and Platt's automatic gear on to the bacteria beds; the effluent therefrom will then be conducted over a prepared irrigation area of about a quarter of an aere in extent; from thence the effluent drains into a ditch.

The surface water passes directly into the ditch. Each section of drains is to be ventilated with an inlet and exhaust ventilator and automatic flushing syphons placed in certain positions, so as to insure a thorough flushing of them.

The whole scheme, inclusive of site, furnishing, and laundry machinery will involve an expenditure of nearly $£ 10,000$-about $\$ 380$ per bed. The reductions and alterations carried out in the amended plans are as follows:

Less bedroom accommodation for nurses; less bathroom and lavatory accommodation; doctor's private sitting-room dispensed with ; bay windows and attics struck out; corridors made narrower; kitchen, which in first scheme was of one story in order to obtain top ventilation and light, is built over to obtain more bedroom accommodation on the first-floor; cellars are now reduced in size, and yard, coal-cellar and out-storeroom struck out.

In Scarlet Block.-Two private wards or day rooms dispensed with, veranda struck out.

In Enteric Block.-Veranda struck out.

In Isolation Block.-Wards revised in size, and half the block struck out.

In Laundry Block.-Foul receiving room, store and engine rooms and yard walls struck out. 
Electric Lighting.-Apparatus and accumulator room struck out. Fence Walling.-Two outfall works and part of hospital site struck out, and creosoted wood-fencing substituted. The whole of the buildings and boundary walling faced with brickwork in place of stone.

Other minor sundry economies.

Estimated total outlay on whole reduced from $£ 13,000$ to about $\mathfrak{1} 10,000$.

I am indebted to Mr. Burrows, the architect, for the loan of the plans and some notes as to the buildings.

The population of the area for which this hospital is to serve is: Birstall, 6,559; Birkenshaw, 2,172; Drighlington, 4,218; Gomersal, 3,580; and Gildersome, 3,073-total, 19,602. The ratable value is $£ 66,283$ 17s. 6 d., necessitating a rate of, in some districts, $3 \mathrm{~d}$. in the $£$, and in others rather more, to repay the amount in twenty-seven years. This is rather heavy in districts where trade is not very flourishing.

Now, the difficulty I wish to point out here is : had the Local Government Board granted a longer term, say forty or fifty years, for the repayment of the loan (and I think the buildings will be good enough for that time), the whole original scheme with a larger number of beds and other accommodation would have been efficiently carried out, and without all the unnecessary delay; and I think this and other kindred societies should make representations to the Local Government Board as to the advisability of granting easier terms of repayment of loans for the carrying out of any work of this character.

Here we are now in the course of erection, it being nearly eight years from the date of our first meeting.

It is expected that the buildings will be completed and ready for oceupation within a year, when I hope the members of the Branch will pay the hospital a visit of inspection.

The death is announced of Dr. John Riddall, Medical Officer of Health for twelve years of the Burgh of Ayr.

Ventilation of Factories.-Sir Walter Foster asked the Home Secretary on November 26th if he had considered the First Report of the Departmental Committee appointed to inquire into the Ventilation of Factories and Workshops, and what steps he proposed to take to carry out the recommendations made therein. Mr. Akers-Douglas replied: This report is receiving very careful consideration, and as a preliminary to deciding what action shall be taken on it, I am having further trials made of the proposed new method of testing the atmosphere in factories. 